\title{
Qualification of the Reclamation Welding Parameters for 316 CRES Stems
}

by

S. R. Howard

Westinghouse Savannah River Company

Savannah River Site

Aiken, South Carolina 29808

G. J. McKinney

\section{MASTER}

DOE Contract No. DE-AC09-89SR18035

This paper was prepared in connection with work done under the above contract number with the U.S. Department of Energy. By acceptance of this paper, the publisher and/or recipient acknowledges the U. S. Government's right to retain a nonexclusive, royalty-free license in and to any copyright covering this paper, along with the right to reproduce and to authorize others to reproduce all or part of the copyrighted paper. 


\section{DISCLAMMER}

This report was prepared as an account of work sponsored by an agency of the United States Government. Neither the United States Government nor any agency thereof, nor any of their employees, makes any warranty, express or implied, or assumes any legal liability or responsibility for the accuracy, completeness, or usefulness of any information, apparatus, product, or process disclosed, or represents that its use would not infringe privately owned rights. Reference herein to any specific commercial product, process, or service by trade name, trademark, manufacturer, or otherwise does not necessarily constitute or imply its endorsement, recommendation, or favoring by the United States Government or any agency thereof. The views and opinions of authors expressed herein do not necessarily state or reflect those of the United States Government or any agency thereof.

This report has been reproduced directly from the best available copy.

Available to DOE and DOE contractors from the Office of Scientific and Technical Information, P. O. Box 62, Oak Ridge, TN 37831; prices available from (423) 576-8401.

Available to the public from the National Technical Information Service, U. S. Department of Commerce, 5285 Port Royal Road, Springfield, VA 22161. 


\section{DISCLAIMER}

Portions of this document may be illegible electronic image products. Images are produced from the best available original document. 
MTS

STRATEGIC MATERIALS DEPARTMENT

Reclamation

Life Storage

Tritium

SRTC Task Job \# 22610

\title{
QUALIFICATION OF THE RECLAMATION WELDING
} PARAMETERS FOR 316 CRES STEMS (U)

\author{
G. J. MCKINNEY \\ S. R. HOWARD
}

September 1997

Classification:
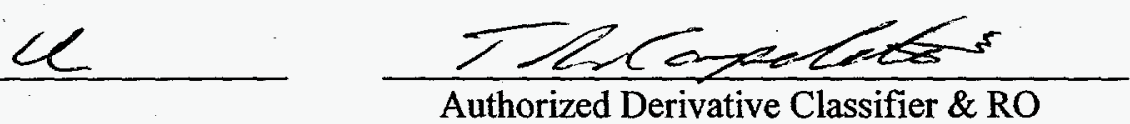

SRTC Savannah River Technology Center, Aiken, SC 29808

Westinghouse Savannah River Company

Prepared by the U.S. Department of Energy Under Contract DE-AC-89SR18035 
DOCUMENT:

IITLE:
WSRC-TR-97-00298

QUALIFICATION OF THE RECLAMATION WELDING

PARAMETERS FOR 316 CRES STEMS (U)
APPROVALS

S. R. Howard,

WEG Cognizant Engineer

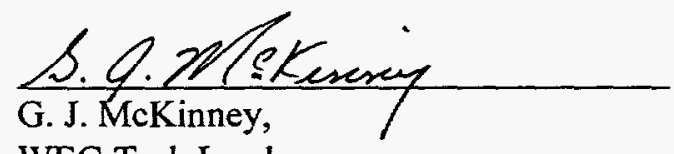

WEG Task Leader

$\frac{\text { U. ZR. Kramer }}{\text { W. R. Kanne, Jr., }}$

Technical Reviewer

$$
\text { ¿ S Sesiens }
$$

C. E. Sessions,

WEG Level 4 Manager

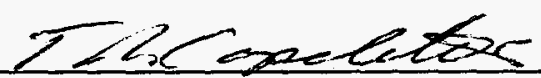

T. L. Capeletti, MTS Level 3 Manager

Nothongen

D. D. Wilhelm,

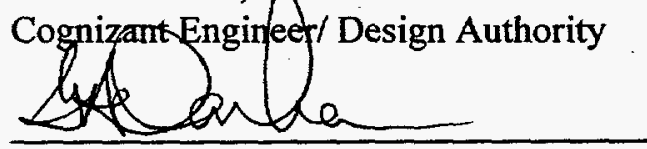

G. A. Donham,

Facility Manager

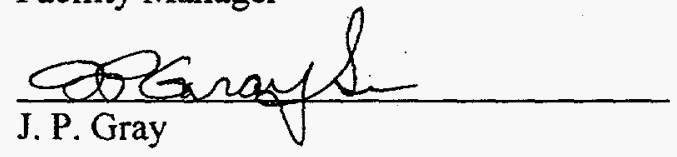

SRTC Cognizant Quality Function
DATE: $10 / 29 / 97$

DATE: $10 / 29 / 97$

DATE: $10 / 30 / 97$

DATE: $10 / 29 / 97$

DATE: $10 / 30 / 97$

DATE: $10 / 7 / 97$

DATE: $10 / 30 / 97$

DATE: $10 / 29 / 97$ 
2.1 Introduction

2.2 Variables

2.3 Acceptance Criteria

3.0 ELEMENTS OF DEMONSTRATION

3.1 Procurement of Test Bases and Stems

3.2 Equipment Upgrades

3.3 Preparation and Evaluation of Welded Coupons

3.4 Equipment Calibration

4.0 RESULTS

4.1 Welding

4.2 Leak/Proof/Burst Tests

4.3 Metallography

5.0 DISCUSSION

5.1 Calibration of 723-A Welder Measuring Equipment 5.2 Metallography Data

6.0 CONCLUSIONS

7.0 REFERENCES

8.0 ACKNOWLEDGMENTS

9.0 FIGURES AND TABLES

10.0 ATTACHMENTS

Attachment A Task Plan 


\section{LIST OF FIGURES AND TABLES}

FIGURE 1 Specially Machined and Standard Test Base Dimensions

FIGURE 2 Typical DAS Test Archive Report

FIGURE 3 Typical Metallographic Cross Section of Reclamation Weld (1.5X)

FIGURE 4 Typical Metallographic Cross Section of Reclamation Weld (100X)

FIGURE 5 Typical Metallographic Cross Section of Reclamation Weld (400X)

TABLE 1 Results of Reclamation Welding Demonstration

TABLE 2 Test Base Dimensions and Usage

TABLE 3 Fill Stem Dimensions and Usage 


\section{Qualification of the Reclamation Welding Parameters \\ for 316 CRES Stems (U) \\ by \\ G. J. McKinney \\ S. R. Howard}

\subsection{SUMMARY}

1.1 A demonstration was performed to prove the acceptability of using existing reclamation weld parameters for joining a new fill stem made of 316 Corrosion Resistant Stainless Steel (CRES) to a 304L stainless steel vessel. Previously qualified weld parameters are for welding the old 0.275 " diameter stem of 304L stainless steel to a $304 \mathrm{~L}$ vessel. The weld quality acceptance criteria included leak rate, proof test, burst strength and evaluation by metallography. All tests and examinations indicated that welds made within the demonstrated parameters met all requirements. The results from this work demonstrate that the welding of 316 CRES $0.275^{\prime \prime}$ diameter stems can be successfully performed using the same weld parameters as those for $304 \mathrm{~L}$ stems.

\subsection{BACKGROUND}

2.1 Introduction - The Weld Engineering Group of the Materials Technology Section of Savannah River Technology Center (SRTC) was requested by Tritium Operations to provide a demonstration to prove the acceptability of using existing weld parameters for future production with $316 \mathrm{~L}$ stem material. To provide a valid demonstration, the reclamation welder in building 723-A was outfitted with current measuring devices and a data acquisition system comparable to those used in the north welder of the production facility. Reclamation welding development, troubleshooting, demonstrations, and comparative tests can now be done conveniently and cost effectively in SRTC.

2.2 Demonstration Variables - All reclamation welding in 723-A was done by joining fill stems to test bases, as essential variables can be cost effectively addressed using test bases. Essential variables such as the fit between the fill stem and counterbore, the welding current, and the initial force applied were varied in this demonstration. These values were varied to produce welds near the parametric limits. Other values easily controlled in production were also controlled in the demonstration. Fill stem foot diameters (see Table 3), the weld cycle time, and the "percent heat" (weld voltage wave form) were held constant. 
2.3 Acceptance Criteria - The acceptance criteria include the following:

Leak Rate

Proof / Burst Strength

Metallography

-Bond Quality

- Bond Line Length
$<5.0$. E-9 std. cc. $\mathrm{He} / \mathrm{sec}^{*}$ (at 1 atm. differential)

$>=$ strength of stem

2.4 Tooling Design- The test base dimensions conform to the specifications identified in Figure 1. The test stems meet the dimension requirements for 304L stems, though they are made of 316 CRES.

\subsection{ELEMENTS OF DEMONSTRATION}

3.1 Procurement of Test Bases and Stems - The 316 CRES test stems were supplied by Sandia National Laboratory/California (SNL/CA) and were produced by hot working, rather than by High Energy Rate Forging (HERF). No certified materials test report was supplied with the stems. The test bases were supplied by Tritium from the routine production test supply. The chemistry of the test bases met commercial specifications for Type 304L stainless steel. The hardness was approximately $91 R_{B}$, which is within the expected $R_{B} 90-100 R_{B}$ hardness value. Some test bases were intentionally remachined to provide weld samples with mating surfaces near the bounds of acceptable counterbore dimensions (see Figure 1).

3.2 Equipment Upgrades - The reclamation welder in 723-A was modified by Engineered Equipment \& Systems (EES) to allow simultaneous recording of data collected from each of several current indicating devices. Graphic printout of data capability was also added (see Figure 2). These modifications made the 723-A welder system comparable to the production systems. The previously used Duffers Scientific current indicating device remained in place for independent, but not time dependent recording of the weld current. The use of Holt Shunt and Robotron current indicating devices make the 723-A and the production systems comparable for developmental, trouble-shooting, and comparative testing activities.

* Std. cc. He/sec : Standard cubic centimeters per second at standard pressure of 14.7 psia and standard temperature of 25 Deg. C. 
3.3 Preparation and Evaluation of Welded Coupons - The demonstration samples were prepared, welded, and examined using the procedures identified in references 7.1 through 7.7. The sample weld quality was evaluated by leak, proof, and burst testing and by metallurgical examination as described below.

\subsubsection{Leak / Proof / Burst Tests - Procedure L9.4-8303 was used by the} High Pressure Laboratory of Savannah River Technology Center (SRTC) for the three load integrity tests. The leak rate test was performed using helium gas as the test fluid. The pressure, range, and maximum acceptable leakage rate were the same as specified in reference 7.12. The hydraulic burst test was performed by increasing the pressure until stem rupture occurred. The proof test acceptance criteria was met before rupture.

\subsubsection{Metallography - The quality of the weld was rated from} metallographic examination as discussed below.

3.3.2.1 Minimum Weld Throat - One measure of weld quality was made by evaluation of minimum weld throat length. The acceptance criteria as identified in SOP MTF-4.15, reference 7.8, requires the weld fusion heights at opposite sides of a weld joint cross section to be greater than $70 \%$ of the height from the top of the base to the bottom of the counterbore.

3.3.2.2 Bond Quality - The appearances of the polished and etched weld cross sections were characterized and assigned bond class ratings identified in references 7.7 and 7.8. A bond rating of Class I or II was required for acceptance. The extent of weld interface area recrystallization was not estimated due to the variations in deformation between the stems and the test bases.

3.4 Equipment Calibration - Calibration of the reclamation welder system in 723-A was performed and documented (Ref. 7.10 and 7.11).

\subsection{RESULTS}

4.1 Welding - Of the 23 stems/bases welded during this demonstration, 18 were within the specified target parameters (Ref. 7.9). The data produced are given in Tables 1 and 2. The data acquisition system for the welder recorded the test variables of current and initial loading forcè (see Figure 2). Other weld parameters were also recorded, but were either not allowed to vary or otherwise remained essentially constant during this demonstration. The percent heat was maintained at $97 \%$ for each weld and the voltage was set to achieve the targeted value of current. Holt current values were used as the primary target for all tests except test numbers 3 and 4 in Table 1, which used the higher amperage Duffers current as the targeted value. 
4.2 Leak / Proof / Burst Tests - Ten of the welds were evaluated by leak rate, proof, and burst testing. The results of all ten leak rate, proof, and burst tests were within the specifications and are given in Table 1 . The leak rates were near the limit of detection and the burst strengths all exceeded 50,000 psig.

4.3 Metallography - Eight of the welds were evaluated by metallography. Table 1 identifies all eight weld coupons which met the stated acceptance criteria concerning bond quality (see Figures 3, 4 and 5) and the required $70 \%$ of the maximum possible throat length of the welded stem/test base combination (Ref. 7.8).

\subsection{DISCUSSION}

5.1 Calibration of 723-A Welder Measuring Equipment The 723-A Reclamation Welder contains calibrated measuring devices coordinated with the Data Acquisition System (DAS). The DAS contains modules which convert the signal outputs for plotting and archiving purposes. Electrode initial force, root mean squared (rms) amperage, weld voltage, wave form, weld cycle time and stem displacement were recorded by the DAS (see Figure 2). Three current measuring devices, the Holt AC Shunt, the Robotron WS-20, and the Duffers Scientific Current Time Analyzer were used for comparative purposes. As on the production facility north welder, the Holt Shunt is used as the primary current measuring device. Calibrations and evaluations of these current measuring devices are documented in References 7.10 and 7.11 .

5.2 Metallography - Weld microstructure was acceptable for all welds made for qualification. The minimum weld throat lengths exceeded the required $70 \%$ of maximum possible throat in all instances. Figures 3 through 5 illustrate the cross section and bond line at different magnifications. All were judged to be acceptable bonds.

\subsection{CONCLUSIONS}

6.1 The previously established welding parameters for the 0.275 in. stem foot diameter 304L stems can be successfully used with 316 CRES stems of the same size.

6.2 Slight adjustments in the actual parameters used in production may be necessary due to system variations from the 723-A welder. Demonstration welds performed during transition work should be evaluated by methods similar to those performed at SRTC before actual production welds are produced. 


\subsection{REFERENCES}

7.1 L9.3-4700 Materials Consultation Work Procedure

7.2 L9.3-4701 Metallurgical Technical Assistance Basis Training and Qualification Procedure

7.3 L9.3-6527 Vibromet Polishing Operations

7.4 L9.3-6533 Olympus Measuring Microscope Operation

7.5 L9.3-8504 Operating Procedure for Reclamation Welder System

7.6 L9.4-8303 Proof/Leak Test Procedure

7.7 SOP MTF-4.14 Rev. 3, Metallurgical Evaluation of Pinch Weld Bonds, Manual L11.1.

7.8 SOP MTF-4.15 Rev. 1, Metallurgical Evaluation of Reclamation Welds, Manual L11.1.

7.9 Letter G. J. McKinney, S. R. Howard, \& C. E. Sessions, to E. G. Caveness, Task Scope, SRT -MTS-5070, June 6, 1997.

7.10 Calibration Report - 723-A Reclamation Welder, Holt Shunt, SRT IES 97037, James Tarpley to Charles Sessions, et al., September 4, 1997.

7.11 Evaluation of Four Robotron Model WS-20 Resistance Welding Current Monitors, Report Number 96-01003, High Current Technologies, Inc., December 10, 1996.

\subsection{SOP RF-H-505 Rev. 2}

\subsection{ACKNOWLEDGMENTS}

8.1 This activity was funded by Tritium Operations as a three part effort as discussed in the memo SRT-MTS-5070, reference 7.9 given as Attachment A of this report. The north welder in the production facility has been upgraded to measure welding current with a Holt Shunt. A similar modification to use the Holt Shunt is planned for the production facility south welder . 


\subsection{Personnel -}

Weld Engineering Group Task Leader - G. J. McKinney

Welding Engineer - S. R. Howard

Metallography Laboratory of Material Technology Section - T. Stefek

SRTC Quality Engineer - J. P. Gray

Instrumentation and Examination Systems Cognizant Engineer- J. M. Tarpley

High Pressure Laboratory of Special Processes Section - D. J. Trapp \& R. W. Good

Facility Manager - G. A. Donham

Cognizant Engineer/Design Authority - D. D. Wilhelm

\subsection{FIGURES AND TABLES}

FIGURE 1 Specially Machined and Standard Test Base Dimensions

FIGURE 2 Typical DAS Test Archive Report

FIGURE 3 Typical Metallographic Cross Section of Reclamation Weld (1.5X)

FIGURE 4 Typical Metallographic Cross Section of Reclamation Weld (100X)

FIGURE 5 Typical Metallographic Cross Section of Reclamation Weld (400X)

TABLE 1 Results of Reclamation Welding Demonstration

TABLE 2 Test Base Dimensions and Usage

TABLE 3 Fill Stem Dimensions and Usage

\subsection{ATTACHMENTS}

Attachment A Table 1, Task Plan 


\section{FIGURE 1}

Specially Machined and Standard Test Base Dimensions for Reclamation Welds

Specially Machined Dimensions

\section{$\mathrm{A}=$ Leave as is}

$\mathrm{B}=0.285^{\prime \prime}+/-0.010^{\prime \prime}$

$C=0.250^{\prime \prime}+0.003^{\prime \prime},-0.001^{\prime \prime}$

(for \#'s 1B -8B);

$\mathrm{C}=0.256^{\prime \prime}+0.001^{\prime \prime},-0.003^{\prime \prime}$

(for \#'s 9B-12B \& \#21-24)

$\mathrm{D}=0.091 "+/-0.003 "$

$E=0.075^{\prime \prime}+/-0.001$

Hole F, Drill thru piece with same

diameter, $+/-0.0015^{\prime \prime}$

$C^{\prime}$ sink angle $=43-47$ degrees

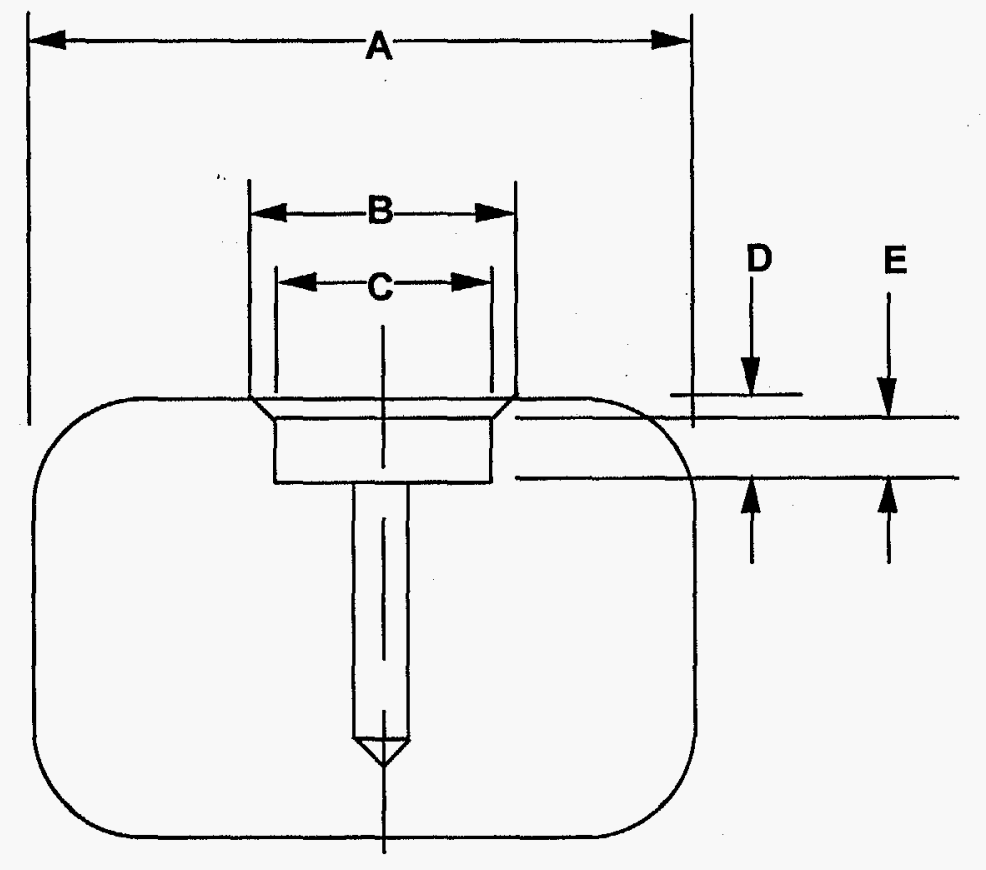

Standard Dimensions

$A=0.967 "-0.966^{\prime \prime}$

$\mathrm{B}=0.275^{\prime \prime}-0.295^{\prime \prime}$

$\mathrm{C}=0.249^{\prime \prime}-0.257^{\prime \prime}$

$\mathrm{D}=0.088^{\prime \prime}-0.094^{\prime \prime}$

$E=0.074 "-0.076 "$ page 7 


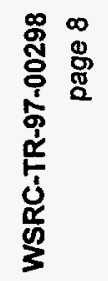
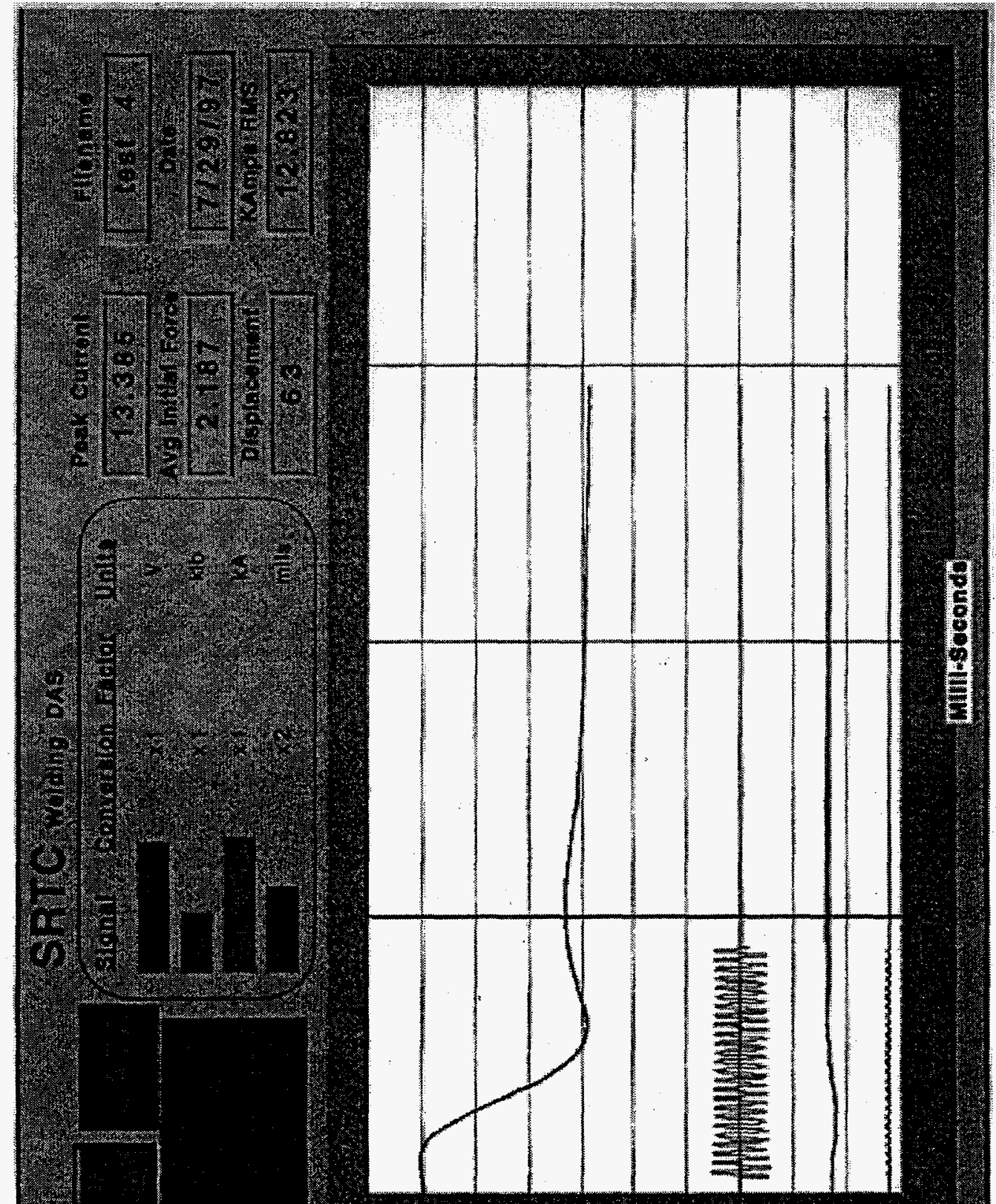

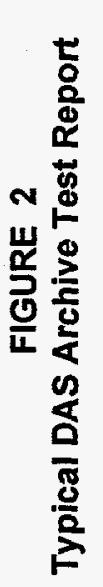


FIGURE 3

Typical Metallographic Cross Section

of Reclamation Weld (1.5X), (below)

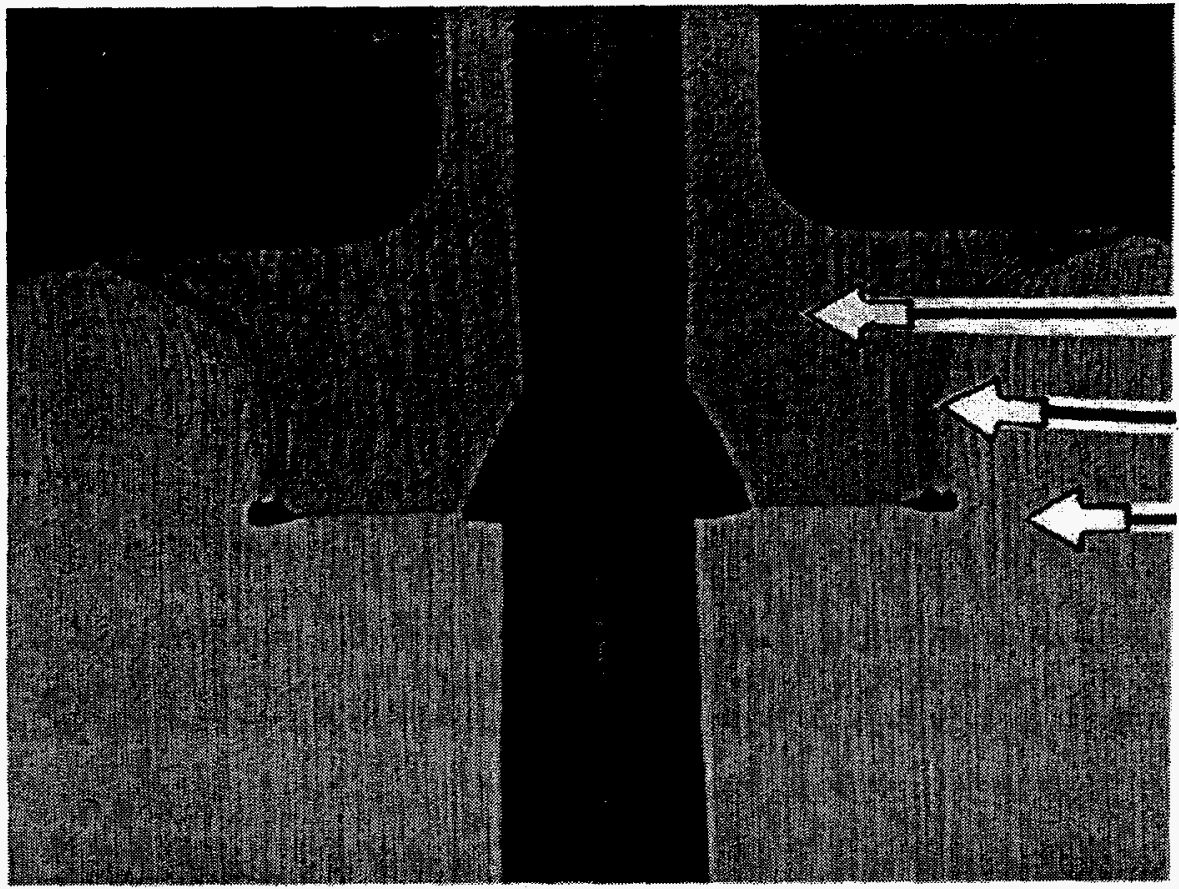

FIGURE 4

Typical Metallographic Cross Section of Reclamation Weld (100X), (below)

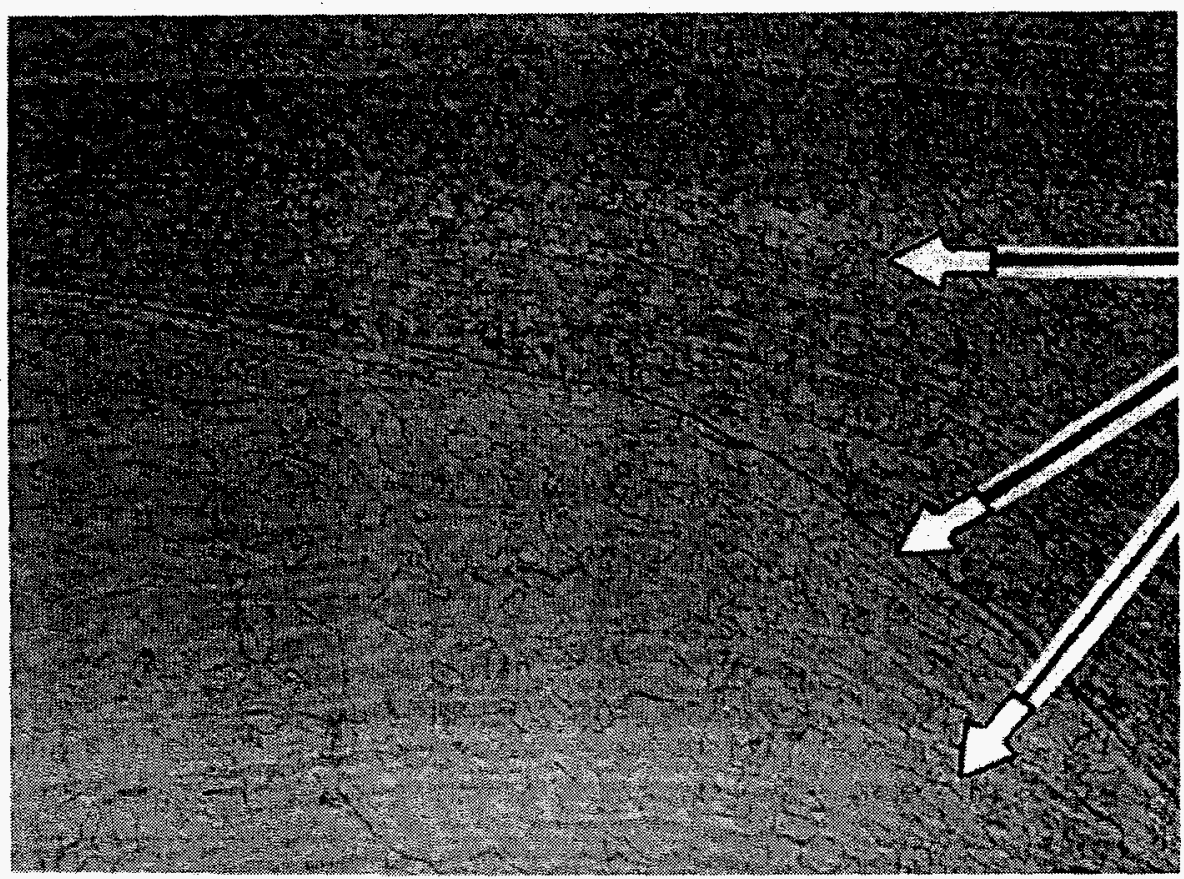

WSRC-TR-97-00298

page 9

Fill Stem Foot Base Metal

Solid State Bond

Test Base Metal

Fill Stem Foot Base Metal

Solid State Bod Interface

Test Base Metal 
FIGURE 5

Typical Metallographic Cross Section

of Reclamation Weld (400X), (below)
WSRC-TR-97-00298

page 10

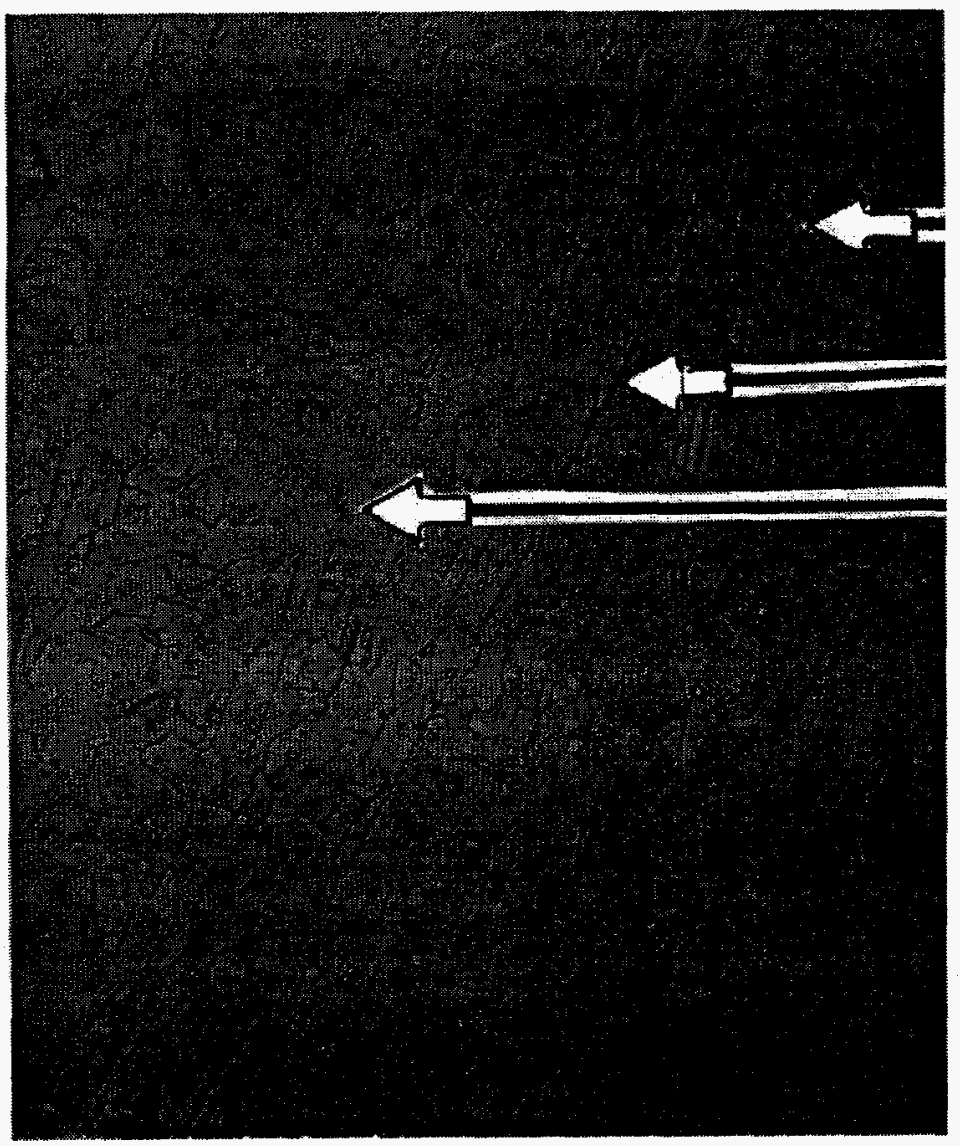

Fill Stem Foot Base Metal

Solid State Bond Interface

Test Base Metal 
TABLE 1

Results of Reclamation Welding Demonstration

for Reclamation Welds

\begin{tabular}{|c|c|c|c|c|c|c|c|c|c|c|c|c|}
\hline Test \# & Weld & Voltage & Duffer & Holt & Force & Counter & Interference & Pass & Pass & Pass & Pass & Pass \\
\hline & & & Current & Current & (Ibs.) & Bore Dia. & (in.) & Leak & Proof & Burst & Bond & Dimension \\
\hline & & & (AMPS) & (AMPS) & & (in) & & Test & Test & Test & Quality & Criteria \\
\hline & & & & & & & & & & & & \\
\hline 1 & Nom. & 330 & 12,380 & 11,314 & 2,244 & 0.251 & 0.0246 & YES & YES & YES & & \\
\hline 2 & Nom. & 327 & 12,330 & 11,315 & 2,239 & 0.252 & 0.0235 & YES & YES & YES & & \\
\hline 3 & Hot & 352 & 13,390 & 12,202 & 2,235 & 0.253 & 0.0226 & YES & YES & YES & & \\
\hline 4 & *Hot & 360 & 13,980 & 12,823 & 2,254 & 0.251 & 0.0245 & & & & YES & YES \\
\hline 5 & Nom. & 325 & 12,350 & 11,274 & 2,239 & 0.252 & 0.0235 & YES & YES & YES & & \\
\hline 6 & Nom. & 327 & 12,640 & 11,525 & 2,237 & 0.252 & 0.0235 & YES & YES & YES & & \\
\hline 7 & Nom. & 328 & 12,200 & 11,216 & 2,252 & 0.251 & 0.0245 & & & & YES & YES \\
\hline 8 & Nom. & 324 & 12,270 & 11,177 & 2,248 & 0.252 & 0.0236 & & & & YES & YES \\
\hline 9 & Cold & 310 & 11,300 & 10,307 & 2,270 & 0.2509 & 0.0249 & YES & YES & YES & & \\
\hline 10 & Cold & 316 & 11,960 & 10,923 & 2,274 & 0.2507 & 0.0251 & YES & YES & YES & & \\
\hline 11 & Cold & 317 & 11,830 & 10,741 & 2,286 & 0.2512 & 0.0246 & & & & YES & YES \\
\hline 12 & Cold & 319 & 12,100 & 11,001 & 2,269 & 0.2506 & 0.0252 & & & & YES & YES \\
\hline 13 & ${ }^{*}$ Cold & 285 & 10,110 & 9,200 & 2,278 & 0.2501 & 0.0259 & YES & YES & YES & & \\
\hline 14 & ${ }^{*}$ Cold & 290 & 10,640 & 9,700 & 2,271 & 0.2504 & 0.0255 & & & & YES & YES \\
\hline 15 & Hot & 338 & 12,740 & 11,650 & 2,224 & 0.2565 & 0.0188 & YES & YES & YES & & \\
\hline $16-1$ & Hot & 337 & 12,690 & 11,661 & 2,219 & 0.2562 & 0.0192 & YES & YES & YES & & \\
\hline $18-1$ & Hot & 341 & 12,390 & 11,762 & 2,219 & 0.2564 & 0.0188 & & & & YES & YES \\
\hline $993-04$ & Hot & 338 & 13,070 & 11,800 & 2,209 & 0.2563 & 0.0186 & & & & YES & YES \\
\hline & & & & & & & & & & & & \\
\hline & & & & & & & & & & & & \\
\hline & & & & & & & & & & & & \\
\hline & & & & & & & & & & & & \\
\hline
\end{tabular}

* Out of spec. range. All welds made using $97 \%$ heat and 25 cycles welding time. 
TABLE 2

Test Base Dimensions and Usage for Reclamation Welds
WSRC-TR-97-00298

page 12

\begin{tabular}{|c|c|c|c|c|c|c|c|}
\hline $\begin{array}{l}\text { Test } \\
\text { Base } \\
\text { Serial } \\
\text { No. }\end{array}$ & $\begin{array}{c}\text { "B" C'sink Diameter } \\
\left(0.275^{n} . .294^{n}\right) \\
0.275-0.281=\mathrm{S} \\
0.282-0.287=\mathrm{M} \\
0.288-0.294=\mathrm{L}\end{array}$ & $\begin{array}{l}\text { "C" C'bore } \\
\text { Diameter } \\
(0.249-257 ") \\
0.249-0.253=S \\
0.254-0.257=L\end{array}$ & $\begin{array}{c}\text { "D" C'bore + C'sink } \\
\text { Depth } \\
(0.088 \text { "-0.094") } \\
0.088-0.091=\mathrm{S} \\
0.092-0.094=\mathrm{L}\end{array}$ & $\begin{array}{l}\text { "E" C'bore } \\
\text { Depth Only } \\
\left(" 0.074^{\prime \prime}-0.076^{n}\right)\end{array}$ & Usage & Test Type & Other Information \\
\hline $2 \mathrm{~B}$ & $0.279 \mathrm{~S}$ & $0.2504 \mathrm{~S}$ & $0.092 \mathrm{~L}$ & 0.075 & Test $14 w \# 191$ & Metallography & Test 14 OK, cold \\
\hline $3 \mathrm{~B}$ & $0.286 \mathrm{M}$ & $0.2562 \mathrm{~L}$ & $0.093 \mathrm{~L}$ & 0.075 & Test $16 w \# 194$ & Not Tested & Hold - 300 Amps too low \\
\hline $4 \mathrm{~B}$ & $0.285 \mathrm{M}$ & $0.2565 \mathrm{~L}$ & $0.091 \mathrm{~s}$ & 0.075 & Test 15 w 169 & $L, P, B$ & Test $15 \mathrm{OK}$, hot \\
\hline $5 B$ & $\wedge .279 \mathrm{~S}$ & $0.2509 \mathrm{~S}$ & $0.091 \mathrm{~S}$ & 0.075 & Test 9 w 104 & $L, P, B$ & Test 9 , cold \\
\hline$\overline{6 B}$ & $0.286 \mathrm{M}$ & $0.2503 \mathrm{~S}$ & $0.091 \mathrm{~S}$ & 0.075 & Test 993-02 w/ \#134 & Burst Test Only & Do not use, met no target \\
\hline $7 \mathrm{~B}$ & $\wedge .285 \mathrm{M}$ & $0.2564 \mathrm{~L}$ & $0.093 \mathrm{~L}$ & 0.075 & Test 18 w 149 & Not Tested & Hold - 300 Amps too low \\
\hline $8 B$ & $0.284 \mathrm{M}$ & $0.2502 \mathrm{~S}$ & $0.091 \mathrm{~s}$ & 0.075 & Test $993-03 w / \# 119$ & Burst Test Only & Do not use, met no target \\
\hline $9 \mathrm{~B}$ & $0.286 \mathrm{M}$ & $0.256 \mathrm{~L}$ & $0.091 \mathrm{~S}$ & 0.075 & Test 993-04 w/ \#111 & No hardness, Metallography & Test $17 \mathrm{OK}$, hot \\
\hline $10 \mathrm{~B}$ & $0.286 \mathrm{M}$ & $0.2563 \mathrm{~L}$ & $0.091 \mathrm{~S}$ & 0.075 & Test 993-01 w/ \#122 & No hardness, Metallography & Low F, low Amps, do not use \\
\hline $11 B$ & $\wedge 0.287 \mathrm{M}$ & $0.2555 \mathrm{~L}$ & $0.092 L$ & 0.075 & Test $16.1 \mathrm{w} 135$ & $L, P, B$ & Test $16.1 \mathrm{OK}$, hot, $2^{\text {nd }}$ try at 16 \\
\hline $12 \mathrm{~B}$ & $\wedge 0.285 \mathrm{M}$ & $0.2561 \mathrm{~L}$ & $0.092 \mathrm{~L}$ & 0.075 & Test $18.1 \mathrm{w} 181$ & Metallography & Test $18.1 \mathrm{OK}$, hot, $2^{\text {nd }}$ try at 18 \\
\hline $13 \mathrm{~B}$ & $\wedge .280 \mathrm{~S}$ & $0.2501 \mathrm{~S}$ & $0.092 \mathrm{~L}$ & 0.075 & Test 13 w 131 & $L, P, B$ & Test 13 OK, cold, out of spec. \\
\hline $3^{*}$ & $0.286 \mathrm{M}$ & $0.251 \mathrm{~S}$ & $0.092 \mathrm{~L}$ & - & Test $1 \mathrm{w} 176$ & $L, P, B$ & Test 1, OK, nom. \\
\hline $4^{*}$ & $0.283 \mathrm{M}$ & $0.252 \mathrm{~S}$ & $0.091 \mathrm{~S}$ & - & Test 6 w 173 & L, P,B & Test 6 OK, nom. \\
\hline $7^{\star}$ & $0.290 \mathrm{~L}$ & $0.251 \mathrm{~S}$ & $0.094 \mathrm{~L}$ & - & Test 7 w 185 & Metallography & Test 7 OK, hot \\
\hline $12^{*}$ & $0.282 \mathrm{M}$ & $0.251 \mathrm{~S}$ & $0.091 \mathrm{~S}$ & - & Test 4 w 145 & Metallography & Test $4 \mathrm{OK}$, hot \\
\hline $15^{*}$ & $0.280 \mathrm{~S}$ & $0.252 \mathrm{~S}$ & $0.089 \mathrm{~S}$ & - & Test 8 w 124 & Metallography & Test $8 \mathrm{OK}$, nom \\
\hline $16^{*}$ & $0.280 \mathrm{~S}$ & $0.253 \mathrm{~S}$ & $0.090 \mathrm{~S}$ & - & Test $3 w 136$ & $L, P, B$ & Test 3 OK, hot \\
\hline $18^{*}$ & $0.285 \mathrm{M}$ & $0.252 \mathrm{~S}$ & $0.092 \mathrm{~L}$ & - & Test 5 w 171 & $L, P, B$ & Test 5 OK, nom. \\
\hline $20^{*}$ & $0.287 \mathrm{M}$ & $0.252 \mathrm{~S}$ & $0.092 \mathrm{~L}$ & - & Test 2 w 139 & $L, P, B$ & Test 2 OK, nom. \\
\hline 21 & $\wedge 0.282 \mathrm{M}$ & $0.2507 \mathrm{~S}$ & $0.092 \mathrm{~L}$ & 0.075 & Test 10 w 167 & $\mathrm{~L}, \mathrm{P}, \mathrm{B}$ & Test $10 \mathrm{OK}$, cold \\
\hline 23 & $\wedge .280 \mathrm{~S}$ & $0.2506 \mathrm{~S}$ & 0.091 & 0.075 & Test 12 w 110 & Metallography & Test 12 OK, cold \\
\hline 24 & $\wedge 0.282 \mathrm{M}$ & $0.2512 \mathrm{~S}$ & 0.093 & 0.075 & Test 11 w 178 & Metallography & Test $11 \mathrm{OK}$, cold \\
\hline spare1 & NA & NA & NA & - & Setup \#107 & None & Initial Demo Setup \\
\hline spare2 & $\mathrm{NA}$ & NA & NA & - & Setup \#108 & None & Initial Demo Setup \\
\hline
\end{tabular}

* Transcribed from originals by Stan Howard, 7/9/97, from SOP RF-H-208 r. 4, Test Weld Data Sheet.

$\wedge$ Transcribed from metrologist report, 7/11/97 SRH.

- Measurement not taken, as all previous were exactly as required. 
TABLE 3

Fill Stem Dimensions and Usage

page 13

316SS Stems for Reclamation Welds

Part Number 458572-00

\begin{tabular}{|c|c|c|}
\hline $\begin{array}{l}\text { Fill Stem } \\
\text { Serial No. }\end{array}$ & $\begin{array}{c}\text { Stem Foot } \\
\text { Size, inches }\end{array}$ & Usage \\
\hline$\times 102$ & 0.2757 & SRTC RW Setup \#107 \\
\hline $\mathrm{X} 104$ & 0.2758 & Test 9 w/Base 5B \\
\hline $\mathrm{X} 110$ & 0.2758 & Test 12 w/Base 23 \\
\hline $\mathrm{X} 111$ & 0.2749 & T 993-04 w/Base 9B (17) \\
\hline $\mathrm{X} 119$ & 0.2761 & Test 993-03 w/Base 8B \\
\hline $\mathrm{X} 122$ & 0.2753 & Test $993-01$ w/Base 10B \\
\hline $\mathrm{X} 124$ & 0.2756 & Test 8 w/Base 15 \\
\hline $\mathrm{X} 128$ & 0.2756 & SRTC RW Setup \\
\hline $\mathrm{X} 131$ & 0.2760 & Test $13 \mathrm{w} /$ Base $13 \mathrm{~B}$ \\
\hline $\mathrm{X} 134$ & 0.2760 & Test 993-02 w/Base 6B \\
\hline$\times 135$ & 0.2754 & Test $16.1 \mathrm{w} /$ Base $11 \mathrm{~B}$ \\
\hline $\mathrm{X} 136$ & 0.2756 & Test 3 w/Base 16 \\
\hline $\mathrm{X} 139$ & 0.2755 & Test 2 w/Base 20 \\
\hline $\mathrm{X} 145$ & 0.2755 & Test 4 w/Base 4 \\
\hline $\mathrm{X} 149$ & 0.2752 & Test 18 w/Base $7 \mathrm{~B}$ \\
\hline $\mathrm{X} 165$ & 0.2755 & SRTC RW Setup \#108 \\
\hline$\times 167$ & 0.2758 & Test 10 w/Base 21 \\
\hline $\mathrm{X} 169$ & 0.2753 & Test 15 w/Base 4B \\
\hline $\mathrm{X} 171$ & 0.2755 & Test 5 w/Base 18 \\
\hline $\mathrm{X} 173$ & 0.2755 & Test 6 w/Base 4 \\
\hline $\mathrm{X} 176$ & 0.2756 & Test 1 w/Base 3 \\
\hline $\mathrm{X} 178$ & 0.2758 & Test 11 w/Base 24 \\
\hline $\mathrm{X} 181$ & 0.2753 & Test $18.1 \mathrm{w} / \mathrm{Base} 12 \mathrm{~B}$ \\
\hline$\times 185$ & 0.2755 & Test 7 w/Base 7 \\
\hline $\mathrm{X} 191$ & 0.2759 & Test 14 w/base $2 B$ \\
\hline $\mathrm{X} 194$ & 0.2754 & Test 16 w/base $3 B$ \\
\hline
\end{tabular}

Measured by Gregg Goff, 6/13/97, digital micrometer \# EA-115, cal. due date 12/18/97.

Checked by Stan Howard, 6/13/97. 


\section{Attachment A}

Task Plan for Reclamation Welding Test Bases with 316 SS Stems

\begin{tabular}{|c|c|c|c|c|c|c|c|c|c|c|c|}
\hline No. & $\begin{array}{c}\text { TB* } \\
\text { or } \\
\text { Other }\end{array}$ & $\begin{array}{c}\text { Voltage } \\
\text { Range }\end{array}$ & $\begin{array}{c}\text { Current } \\
\text { Target } \\
\text { Range }\end{array}$ & Force & Time & $\begin{array}{c}\text { C'Bore } \\
\text { Size }\end{array}$ & $\begin{array}{c}\text { Stem } \\
\text { Foot } \\
\text { Size }\end{array}$ & $\begin{array}{l}\text { Leak } \\
\text { Test }\end{array}$ & $\begin{array}{l}\text { Proof } \\
\text { Test }\end{array}$ & $\begin{array}{l}\text { Burst } \\
\text { Test }\end{array}$ & Metallography \\
\hline 1 & TB & TBD & Nom. & Nom. & Nom. & Nom. & $\mathrm{a}^{*}$ & $\mathrm{X}$ & $\mathrm{X}$ & $\mathrm{X}$ & \\
\hline 2 & TB & TBD & Nom. & Nom. & Nom. & Nom. & $\mathrm{a}^{*}$ & $\mathrm{X}$ & $\mathrm{X}$ & $\mathrm{X}$ & \\
\hline 3 & TB & TBD & Nom. & Nom. & Nom. & Nom. & $\mathrm{a}^{*}$ & & & & $\mathrm{X}$ \\
\hline 4 & TB & TBD & Nom. & Nom. & Nom. & Nom. & $\mathrm{a}^{*}$ & & & & $\mathrm{X}$ \\
\hline 5 & TB & TBD & Nom. & Nom. & Nom. & Nom. & $\mathrm{a}^{*}$ & $\mathrm{X}$ & $\mathrm{X}$ & $\mathrm{X}$ & \\
\hline 6 & TB & TBD & Nom. & Nom. & Nom. & Nom. & $\mathrm{a}^{*}$ & $\mathrm{X}$ & $\mathrm{X}$ & $\mathrm{X}$ & \\
\hline 7 & TB & TBD & Nom. & Nom. & Nom. & Nom. & $\mathrm{a}^{*}$ & & & & $\mathrm{X}$ \\
\hline 8 & TB & TBD & Nom. & Nom. & Nom. & Nom. & $\mathrm{a}^{*}$ & & & & $\mathrm{X}$ \\
\hline 9 & TB & TBD & Low & High & Nom. & Min. & $\mathrm{a}^{*}$ & $\mathrm{X}$ & $\mathrm{X}$ & $\mathrm{X}$ & \\
\hline 10 & TB & TBD & Low & High & Nom. & Min. & $\mathrm{a}^{*}$ & $\mathrm{X}$ & $\mathrm{X}$ & $\mathrm{X}$ & \\
\hline 11 & TB & TBD & Low & High & Nom. & Min. & $\mathrm{a}^{*}$ & & & & $\mathrm{X}$ \\
\hline 12 & TB & TBD & Low & High & Nom. & Min. & $\mathrm{a}^{*}$ & & & & $\mathrm{X}$ \\
\hline 13 & TB & TBD & $\begin{array}{c}\text { L (out } \\
\text { of spec) }\end{array}$ & High & Nom. & Min. & $\mathrm{a}^{*}$ & $\mathrm{X}$ & $\mathrm{X}$ & $\mathrm{X}$ & \\
\hline 14 & TB & TBD & $\begin{array}{c}\text { L (out } \\
\text { of spec) }\end{array}$ & High & Nom. & Min. & $\mathrm{a}^{*}$ & & & & \\
\hline 15 & TB & TBD & High & Low & Nom. & Max. & $\mathrm{a}^{*}$ & $\mathrm{X}$ & $\mathrm{X}$ & $\mathrm{X}$ & $\mathrm{X}$ \\
\hline 16 & TB & TBD & High & Low & Nom. & Max. & $\mathrm{a}^{*}$ & $\mathrm{X}$ & $\mathrm{X}$ & $\mathrm{X}$ & \\
\hline 17 & TB & TBD & High & Low & Nom. & Max. & $\mathrm{a}^{*}$ & & & & $\mathrm{X}$ \\
\hline 18 & TB & TBD & High & Low & Nom. & Max. & $\mathrm{a}^{*}$ & & & & $\mathrm{X}$ \\
\hline 19 & NA & & & & & & & & & & \\
\hline 20 & NA & & & & & & & & & & \\
\hline
\end{tabular}

a - KC produced WR stems to be sorted by foot diameter and selected to produce the desired effects on a best effort basis.

NA- not specified

(sequence of welding to be randomized) 